Sains Malaysiana 49(2)(2020): 261-270

http://dx.doi.org/10.17576/jsm-2020-4902-04

\title{
ACE-Inhibitory and Antioxidant Activities of Hydrolysates from the By-Products of Hybrid Grouper (Epinephelus lanceolatus $\times$ Epinephelus fuscoguttatus)
}

(Aktiviti Perencantan-ACE dan Antioksidan Hidrolisat daripada Hasil Sampingan Ikan Kerapu Kacukan (Epinephelus lanceolatus $\times$ Epinephelus fuscoguttatus))

\author{
Pei-Teng, Chan, Patricia Matanjun, Cahyo Budiman, Rossita Shapawi \& Jau-Shya, LeE*
}

\begin{abstract}
Protein hydrolysates, generated from the by-products of fish, have received much attention over recent years, due to their antihypertensive and antioxidant activities. The potency of bioactive peptides, however, is affected by the type of enzyme selected and the duration of hydrolysis required to generate the protein hydrolysate. This study was aimed to investigate the effects of using four different enzymes (Alcalase, Proteinase K, Trypsin, and Pepsin) and hydrolysis time (1 - 48 h), on the ACE-inhibitory and antioxidant activities (hydroxyl radical scavenging activity and reducing power), of protein hydrolysates from the head and bones of hybrid grouper (Epinephelus lanceolatus $\times$ Epinephelus fuscoguttatus). Among the enzymes tested, Alcalase was the most effective enzyme hydrolysing the by-product of hybrid grouper, followed by Proteinase K, Trypsin, and Pepsin $(p<0.05)$. According to the results attained, enzyme with the higher degree of hydrolysis exhibited higher antioxidant activities, but not ACE-inhibitory activity. This indicates that the ACEinhibition potency of hydrolysate, from the by-product of hybrid grouper, is very much dependent on the type of enzyme, and the treatment duration during hydrolysis. The ACE-inhibitory activity of Alcalase and Trypsin hydrolysates was found to decrease in tandem with the increase in hydrolysis time. On the other hand, a longer hydrolysis time resulted in a higher ACE-inhibitory activity for Proteinase K and Pepsin hydrolysate $(p<0.05)$. The results attained suggest that the selection of an appropriate enzyme, together with an effective hydrolysis time, can enhance the bioactivities of the hydrolysate obtained from the by-product of hybrid grouper.
\end{abstract}

Keywords: ACE-inhibitory activity; Alcalase; Pepsin; Proteinase K; Trypsin

\section{ABSTRAK}

Kebelakangan ini, hidrolisat protein yang dihasilkan daripada bahan sampingan ikan telah mendapat banyak tumpuan disebabkan keupayaannya menunjukkan aktiviti antihipertensi dan antiosidan. Potensi bioaktif peptida bagaimanapun dipengaruhi oleh jenis enzim dan tempoh hidrolisis yang digunakan untuk menghasilkan hidrolisat protein. Kajian ini bertujuan untuk mengkaji kesan enzim (Alkalase, Proteinase K, Tripsin, dan Pepsin) dan masa hidrolisis (1 - 48 jam) yang berbeza terhadap aktiviti perencatan-ACE dan antioksidan (aktiviti pemerangkapan radikal hidroksil dan kuasa penurunan) hidrolisat yang dihasilkan daripada kepala dan tulang ikan kerapu kacukan (Epinephelus lanceolatus $\times$ Epinephelus fuscoguttatus). Antara enzim yang digunakan, Alkalase merupakan enzim yang paling berkesan untuk menghidrolisiskan hasil sampingan ikan kerapu kacukan, diikuti dengan Proteinase K, Tripsin dan Pepsin (p < 0.05). Berdasarkan hasil kajian yang diperoleh, enzim dengan darjah hidrolisis yang tinggi merekodkan aktiviti antioksidan yang tinggi tetapi tidak dengan aktiviti perencatan-ACE. Ini menunjukkan potensi aktiviti perencatan-ACE hidrolisat daripada hasil sampingan ikan kerapu kacukan amat bergantung kepada jenis enzim dan masa rawatan sewaktu hidrolisis. Aktiviti perencantan-ACE bagi hidrolisat Alkalase dan Tripsin didapati menurun dengan peningkatan masa hidrolisis. Sebaliknya, masa hidrolisis yang panjang mengakibatkan aktiviti perencatan-ACE yang lebih tinggi bagi hidrolisat Proteinase K dan Pepsin ( $2<0.05)$. Hasil keputusan kajian ini mencadangkan bahawa pemilihan enzim yang betul digabungkan dengan masa hidrolisis yang berkesan dapat menambahbaikan bioaktiviti hidrolisat yang diperoleh daripada hasil sampingan ikan kerapu kacukan.

Kata kunci: Aktiviti perencantan-ACE; Alkalase; Pepsin; Proteinase K; Tripsin

\section{INTRODUCTION}

Hypertension had been identified as a major contributor towards cardiovascular diseases such as heart disease and stroke. According to a World Health Organization (WHO) report, hypertension accounts for 9.4 million annual deaths worldwide (WHO 2013). Over recent years, researchers have been investigating ways to prevent, as well as to treat hypertension. Synthetic angiotensin-I converting enzyme (ACE)-inhibitors such as captopril and enalapril, have been used for the treatment for hypertension and heart failure in human. Unfortunately, these drugs have been observed to come with side effects that include cough, taste 
disturbance, and skin rash (Kim \& Wijesekara 2012). As such, food-derived antihypertensive agents have attracted much attention because their usage is devoid of any no side effects (Kawasaki et al. 2000). The overproduction of free radicals in the human body causes many degenerative diseases. These include brain dysfunction, heart disease, cancer, and immune system deterioration (Ktari et al. 2012). Antioxidants are substances that can scavenge and inhibit the production of these excess free radicals. Similar to the synthetic ACE-inhibitor, the utilisation of strictly regulated synthetic antioxidants, such as butylated hydroxytoluene (BHT), can bring about negative effects on human health (Chi et al. 2015). This situation has served to intensify the need for antioxidants deriving from natural sources.

Grouper fish is belonging to a family of predatory marine species, whose habitat stretches throughout the world's tropical and subtropical seas. Crossbreeding, involving the giant grouper and the tiger grouper, resulted in the hybrid grouper TGGG. Of late, this hybrid grouper has been drawing the attention of players in the aquaculture industry. This can be put down to its fast growth rate, high tolerance to low salinity, and increased consumer demand (De et al. 2014; Firdaus et al. 2016). With the high demand for this hybrid grouper (especially in terms of fish fillet), a considerable amount of processing leftover (fish head, trimming, and viscera) is generated from the filleting process. Instead of being simply discarded, these byproducts can be converted into high value functional ingredients. Previous studies have reported that byproducts from fish contain a high amount of protein (15 - 80\%). As such, these by-products have the potential to be an effective substrate for the production of protein hydrolysates (Jai Ganesh et al. 2011; Zuraini et al. 2006). Protein hydrolysates produced from the by-products of fish exhibit an array of bioactivities. These include ACEinhibitory, antioxidant, and antimicrobial activities (Ennaas et al. 2015; Je et al. 2007; Najafian \& Babji 2014; Qian et al. 2007). The fish protein hydrolysates with antihypertensive properties, currently available in the market for human consumption, are commercial supplements such as Vasotensin and PeptACE (Chalamaiah et al. 2012). Other than their biological benefits, food peptides also hold an advantage over other natural bioactive compounds (such as polyphenols), as they come with a variety of functional properties (Ambigaipalan \& Shahidi 2015; FrancoMiranda et al. 2017). The hydrophobic and hydrophilic characteristics of peptides contribute towards their physicochemical properties, which includes solubility, and the capacity for water holding and emulsification. These physicochemical properties have been observed to be beneficial, in the context of processed foods. Snakehead hydrolysate, with its high antioxidant activity, can stabilise the emulsion formed in sausages. This is achieved through the formation of an interfacial thin film around the fat globules, which also serves to improve the texture of the sausages (Zakaria \& Sarbon 2018).

Enzymatic hydrolysis, using commercially available proteases, is the preferred method for the production of protein hydrolysates, as it is more controllable. Data from previous studies indicate that protein hydrolysates, with raised ACE-inhibitory and antioxidant activities, can be generated from a variety of enzymes, under different hydrolysis times. As examples, the ACE-inhibitory activity, of the Alcalase hydrolysate generated from the sarcoplasmic protein of patin was greater than that of the Papain hydrolysate (Najafian \& Babji 2014). Li et al. (2014) reported that Alcalase-treated tea seed protein displayed higher antioxidant activities at $2 \mathrm{~h}$ of hydrolysis time than it was at $4 \mathrm{~h}$. Thus, it can be surmised that the type of enzymes used, and the hydrolysis time employed, determines the bioactivity level of protein hydrolysates. Each enzyme comes with its own specificity, and thus reacts differently towards the substrate; meanwhile the duration of hydrolysis affects the extent of the enzymatic hydrolysis. These two factors contribute towards changes in the peptide sequences, and these changes affect the bioactivities of the protein hydrolysates. To date, no studies have been conducted on the production of hydrolysates from the head and bones of hybrid grouper. In order to obtain a hydrolysate with high ACE-inhibitory and antioxidant activities, it is important to determine a suitable enzyme and hydrolysis duration for these by-products. This study investigates the effects resulting from the use of different types of enzymes (Alcalase, Proteinase K, Trypsin, and Pepsin) and hydrolysis times (1 - $48 \mathrm{~h})$ on the ACE-inhibitory and antioxidant activities (hydroxyl radical scavenging activity and reducing power) of protein hydrolysates, from the head and bones of hybrid grouper.

\section{MATERIALS AND METHODS}

\section{SAMPLE PREPARATION}

The hybrid groupers of similar weight (800 - $850 \mathrm{~g}$ ) were bought from Borneo Marine Research Institute, Universiti Malaysia Sabah (UMS). They were filleted, eviscerated and the fish head and bones were collected, then washed twice with distilled water and minced using waring blender. The minced head and bones were then immediately frozen using liquid nitrogen and freeze dried using a freeze dryer (Labconco, FreeZone 12, USA). The rapid freezing using liquid nitrogen introduces smaller ice crystals that can avoid severe damage of the samples tissues due to formation of big ice crystals. Rapid freezing also slowed down proteolytic reaction faster (Coggins \& Chamul 2006). The freeze dried sample was then stored in $-20^{\circ} \mathrm{C}$ until used.

\section{PREPARATION OF PROTEIN HYDROLYSATES}

The freeze dried sample was mixed in buffer at a ratio of 1:50 (w/v), and was separately hydrolysed with four commercially available enzymes, i.e. Alcalase (EC 3.4.21.14), Proteinase K (EC 3.4.21.64), Trypsin (EC 3.4.21.4), and Pepsin (EC 3.4.23.1) at their respective optimum hydrolysis condition as described in Table 1 . The enzyme to sample ratio was set at 1:100 (w/w) (Je et al. 
2007; Najafian \& Babji 2014) and the reaction was conducted in a shaking incubator (Thermo Scientific, Model 481, USA). At each time point (0, 1, 2, 4, 6, 24, and $48 \mathrm{~h}$ ), some sample was drawn and heated at $95^{\circ} \mathrm{C}$ for 15 min to inactive the enzyme. The hydrolysates were then quickly cooled and centrifuged at $10,000 \times \mathrm{g}$ for $20 \mathrm{~min}$ at $4{ }^{\circ} \mathrm{C}$. Part of the supernatant was used to determine the degree of hydrolysis (DH); the remaining supernatant was lyophilised and stored at $-20^{\circ} \mathrm{C}$ for further analysis.

\section{DETERMINATION OF DEGREE OF HYDROLYSIS (DH)}

The DH of the hydrolysates was determined by o-phthaldiadehyde (OPA) method (Mirzaei et al. 2015;
ACE $(25 \mathrm{mU} / \mathrm{mL})$ was added to initiate the reaction and followed by incubation at $37^{\circ} \mathrm{C}$ for $60 \mathrm{~min}$. The reaction was terminated by the addition of $250 \mu \mathrm{L}$ of $1 \mathrm{~N} \mathrm{HCl}$. The released hippuric acid was extracted by the addition of 1.5 $\mathrm{mL}$ ethyl acetate followed by centrifugation at $2000 \times \mathrm{g}$ at $4^{\circ} \mathrm{C}$ for $10 \mathrm{~min}$. The upper layer $(1 \mathrm{~mL})$ was transferred to a new test tube and evaporated at $40^{\circ} \mathrm{C}$ in a vacuum oven (Binder GmbH, VD 23, Germany). Then, $1 \mathrm{~mL}$ of deionised water was added to the test tube and the absorbance of the sample was measured at $228 \mathrm{~nm}$ using a UV-Vis spectrophotometer (Perkin Elmer, Lambda 35, USA). The ACE inhibition activity was calculated using the following equation: Inhibition activity $(\%)=[(\mathrm{A}-\mathrm{B}) /$ $(\mathrm{A}-\mathrm{C})] \times 100 \%$, where $\mathrm{A}$ is the absorbance of control

TABLE 1. Conditions for the hydrolysis of head and bones of hybrid grouper

\begin{tabular}{ccccc}
\hline Enzyme & Source & Buffer & $\mathrm{pH}$ & Temperature $\left({ }^{\circ} \mathrm{C}\right)$ \\
\hline Alcalase & Bacillus licheniformis & $0.1 \mathrm{M} \mathrm{Na}_{2} \mathrm{HPO}_{4}-\mathrm{NaH}_{2} \mathrm{PO}_{4}$ & 7.5 & 50 \\
Proteinase $\mathrm{K}$ & Tritirachium album & $0.1 \mathrm{M} \mathrm{Na}_{2} \mathrm{HPO}_{4}-\mathrm{NaH}_{2} \mathrm{PO}_{4}$ & 7 & 37 \\
Trypsin & Porcine pancreas & $0.1 \mathrm{M} \mathrm{Na}_{2} \mathrm{HPO}_{4}-\mathrm{NaH}_{2} \mathrm{PO}_{4}$ & 8 & 37 \\
Pepsin & Porcine gastric mucosa & $0.1 \mathrm{M} \mathrm{KCl}-\mathrm{HCl}$ & 2 & 37 \\
\hline
\end{tabular}

Nielsen et al. 2001). The OPA reagent was prepared as follows: $7.62 \mathrm{~g}$ disodium tetraborate decahydrate and 200 mg sodium dodecyl sulphate (SDS) were completely dissolved in $150 \mathrm{~mL}$ deionised water. O-phthaldialdehyde (160 mg) was dissolved in $4 \mathrm{~mL}$ ethanol and added to the above-mentioned solution by rinsing with deionised water. Then $176 \mathrm{mg}$ dithiothreitol (DTT) was added to the solution by rinsing with deionised water. Finally, the solution was made up to $200 \mathrm{~mL}$ with deionised water. Sample and serine standard $(0.4 \mathrm{~mL})$ was added to a test tube containing $3 \mathrm{~mL}$ OPA reagent and mixed for $5 \mathrm{~s}$. The mixture was incubated at room temperature for $2 \mathrm{~min}$. Absorbance of the mixture was measured at $340 \mathrm{~nm}$ using UV-Vis spectrophotometer (Perkin Elmer, Lambda 35, USA). The $\mathrm{h}_{\text {tot }}$ was determined by hydrolysing the freeze dried sample with $6 \mathrm{~N} \mathrm{HCl}$ at $110^{\circ} \mathrm{C}$ for $24 \mathrm{~h}$ in the oven (Memmert, UFE 500, Germany). The DH was calculated using the following equation: $\mathrm{DH}(\%)=\mathrm{h}_{\mathrm{t}}-\mathrm{h}_{0} / \mathrm{h}_{\text {tot }} \times 100 \%$, where $h_{t}$ is the amount of amino group released at time $t, h_{0}$ is the amount of amino group in the supernatant at time $0 \mathrm{~h}$, and $\mathrm{h}_{\text {tot }}$ is the total amount of amino group obtained after acid hydrolysis.

\section{DETERMINATION OF ACE-INHIBITORY ACTIVITY OF HYDROLYSATES}

The ACE-inhibitory activity analysis was performed according to Sun et al. (2011) with some modification. Hippuryl-Histidyl-Leucine (HHL) was dissolved in $50 \mathrm{mM}$ sodium borate buffer (pH8.3) containing $0.5 \mathrm{M} \mathrm{NaCl}$ to achieve a final concentration of $8.3 \mathrm{mM}$. A reaction mixture containing $150 \mu \mathrm{L}$ of $\mathrm{HHL}$ and $50 \mu \mathrm{L}$ of sample $(1 \mathrm{mg} / \mathrm{mL})$ was pre-incubated at $37^{\circ} \mathrm{C}$ for $5 \mathrm{~min}$. Subsequently, $50 \mu \mathrm{L}$ (sample replaced with deionised water), $\mathrm{B}$ is the absorbance of the reaction mixture, $\mathrm{C}$ is the absorbance when the stop reaction solution was added before the reaction occurred (blank).

\section{DETERMINATION OF HYDROXYL RADICAL SCAVENGING ACTIVITY}

Hydroxyl radicals were generated by Fenton reaction (Jumeri \& Kim 2011). Reaction mixture containing 0.1 $\mathrm{mL} \mathrm{FeSO}_{4}(10 \mathrm{mM}), 0.1 \mathrm{~mL}$ EDTA $(10 \mathrm{mM}), 0.5 \mathrm{~mL}$ 2-deoxyribose $(10 \mathrm{mM})$, and $0.9 \mathrm{~mL}$ sodium phosphate buffer (0.1 M, pH7.4) was mixed with $0.2 \mathrm{~mL}$ of sample $(2 \mathrm{mg} / \mathrm{mL})$. The reaction was then initiated by the addition of $0.2 \mathrm{~mL}$ of $\mathrm{H}_{2} \mathrm{O}_{2}(10 \mathrm{mM})$. The mixture was then incubated at $37^{\circ} \mathrm{C}$ for $90 \mathrm{~min}$. After that, the reaction was stopped by adding $1 \mathrm{~mL}$ of cold trichloroacetic acid (TCA) $(2 \%)$ and $1 \mathrm{~mL}$ of thiobarbituric acid (TBA) (1\%). The mixture was then heated in a boiling water bath for $15 \mathrm{~min}$. The mixture was cooled to room temperature and the absorbance of the resulting pink colour in the samples was measured at $532 \mathrm{~nm}$ using UV-Vis spectrophotometer (Perkin Elmer, Lambda 35, USA).

\section{DETERMINATION OF REDUCING POWER OF HYDROLYSATES}

The reducing power of the hydrolysates was measured using the method described by Najafian and Babji (2014). A $0.2 \mathrm{~mL}$ of sample aliquot $(0.25 \mathrm{mg} / \mathrm{mL})$ was added to $0.5 \mathrm{~mL} 0.2 \mathrm{M}$ sodium phosphate buffer (pH6.6) and 0.5 $\mathrm{mL}$ of potassium ferricyanide solution (1\%). After incubation at $50^{\circ} \mathrm{C}$ for $20 \mathrm{~min}, 0.5 \mathrm{~mL}$ of TCA $(10 \%)$ was mixed with the reaction mixture, and the reaction mixture 
was centrifuged at $3500 \times \mathrm{g}$ for $10 \mathrm{~min}$ at $4^{\circ} \mathrm{C}$. Finally, 0.5 $\mathrm{mL}$ of the supernatant solution was subsequently added to $0.5 \mathrm{~mL}$ distilled water and $0.1 \mathrm{~mL}$ ferric chloride solution $(0.1 \%)$. After $2 \mathrm{~min}$, the absorbance was measured at 700 nm against blank using UV-Vis spectrophotometer (Perkin Elmer, Lambda 35, USA).

\section{STATISTICAL ANALYSIS}

All analyses were carried out in triplicate and the results were expressed as mean \pm standard deviation. The data obtained were analysed by one-way analysis of variance (ANOVA) followed by Tukey multiple range test using SPSS v.17 for Windows (SPSS, USA). The differences between means were considered significant at $p<0.05$.

\section{RESULTS AND DISCUSSION}

\section{DEGREE OF HYDROLYSIS}

The progress of hydrolysis in term of DH is presented in Figure 1. Among the proteases, Alcalase displayed the highest $\mathrm{DH}(53.12 \%)(p<0.05)$, followed by Proteinase K (41.30\%), Trypsin (15.82\%), and Pepsin (8.29\%). This suggests that Alcalase has a higher affinity towards the protein of the hybrid grouper. Both Alcalase and Proteinase $\mathrm{K}$ exhibited a broad-spectrum hydrolysis that cleaved mainly hydrophobic- $\mathrm{COOH}$, aliphatic and aromatic- $\mathrm{COOH}$. This resulted in a higher DH in comparison to the more specific enzymes i.e. trypsin (cleaved carboxyl side of lysine and arginine only) and pepsin (cleaved carboxyl side of phenylalanine and leucine only) (Adler-Nissen 1993). Alcalase reacted rapidly during the first $6 \mathrm{~h}$ of hydrolysis, and then slowed down to a plateau at $32 \mathrm{~h}$. A similar trend was displayed by Trypsin, albeit at a rate four times slower than Alcalase. The high initial reaction rate, displayed by Alcalase and Trypsin was attributed to the availability of cleavage sites at the beginning of hydrolysis. The reduction in reaction rate at the later stage was due to the decrease in susceptible peptide bonds. Proteinase K displayed the second highest $\mathrm{DH}$ with a higher rate during the first $6 \mathrm{~h}$, followed by linear increments until the $48 \mathrm{~h}$ mark. The lowest hydrolysis rate $(8.29 \% \mathrm{DH})$ was recorded by Pepsin. Unlike Alcalase and Trypsin, the DH for Proteinase $\mathrm{K}$ and Pepsin did not level out following $48 \mathrm{~h}$ of hydrolysis. This indicates the availability of substantial measure of substrate for further reaction.

The high DH exhibited by Alcalase in this study, is in agreement with the findings from investigations on shrimp processing by-products (Huang et al. 2011) and ribbon jellyfish (Barzideh et al. 2014). Contrastingly, studies on tuna backbone and dark muscle showed a higher DH for Pepsin, than for Alcalase and Trypsin (Je et al. 2007; Qian et al. 2007). Choonpicharn et al. (2014) reported that Trypsin is three times more capable than Alcalase, when it comes to the hydrolysis of Nile skin gelatine. This disparity in findings, indicate that DH is determined by the

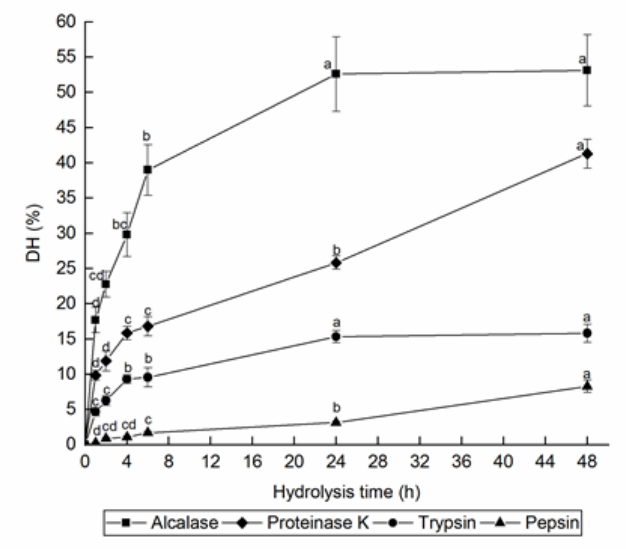

(a-d) different letter within the same line pattern indicates significant difference at $\mathrm{p}<0.05$

FIGURE 1. The degree of hydrolysis (DH) of the head and bone of hybrid grouper treated with four different enzymes, i.e. Alcalase, Proteinase K, Trypsin, and Pepsin

substrate and the enzyme used. Consequently, in order to enhance the effectiveness of the hydrolysis process, it is essential that an appropriate enzyme be selected.

\section{EFFECT OF HYDROLYSIS TIME ON THE ACE-INHIBITORY ACTIVITY OF HYDROLYSATES}

As portrayed in Figure 2, the ACE-inhibitory activity of hydrolysates varies with the alterations in the hydrolysis time. Alcalase recorded the highest ACE-inhibitory activity $(59.12 \%)$ after $1 \mathrm{~h}$ of hydrolysis, with a DH value of $17.70 \%$ (Figure 2(A)). Further hydrolysis of up to $4 \mathrm{~h}$ led to a decline in the ACE-inhibitory activity $(p<0.05)$. However, activity increased slightly between 6 and $24 \mathrm{~h}$, before dipping again to $39.71 \%$ at the $48 \mathrm{~h}$ mark. Similarly, Trypsin hydrolysate displayed the highest ACE-inhibitory activity $(48.64 \%)(p<0.05)$ at the first hour of hydrolysis. Continued hydrolysis for a further $24 \mathrm{~h}$ reduced the activity to $4.68 \%$, and at $48 \mathrm{~h}$ of hydrolysis, all activity ceased with the DH at $15.82 \%$ (Figure 2(B)). This trend indicates that the depletion of bioactive compounds, contributes towards the ACE-inhibitory activity with increasing hydrolysis time. Prolonged hydrolysis by Alcalase and Trypsin led to excessive cleavage of the potent peptides, resulting in more peptides with less active sequences. For the Proteinase K hydrolysate, no ACE-inhibitory activity was recorded during the first hour of hydrolysis (Figure 2(C)). However, hydrolysis up to $2 \mathrm{~h}(\mathrm{DH}=11.88 \%)$ raised the activity to $46.34 \%$. Activity gradually dropped to $21.65 \%$ after $6 \mathrm{~h}$ of hydrolysis $(p<0.05)$. Subsequently, at the $48 \mathrm{~h}$ mark, the ACE-inhibition of the hydrolysate rose to the highest level $(55.92 \%)(p<0.05)$. The ACE-inhibitory activity of the pepsin hydrolysate exhibited a different trend. It peaked at $4 \mathrm{~h}$ of hydrolysis $(50.76 \%)(p<0.05)$, and then continued to decrease until $24 \mathrm{~h}$ of hydrolysis (Figure 2(D)). Further hydrolysis of up to $48 \mathrm{~h}$ elevated the ACE-inhibitory activity to $52.38 \%$, similar to the activity at $4 \mathrm{~h}$ hydrolysis. 
A weak negative correlation $\left(\mathrm{R}^{2}=-0.470\right)(p<0.05)$ was found between the DH and the ACE-inhibitory activity of Alcalase, whereas a strong negative correlation $\left(\mathrm{R}^{2}=\right.$ $-0.977)(p<0.01)$ was observed for Trypsin. This is an indication, that prolonged hydrolysis, does not improve the ACE-inhibitory activity of the Alcalase and Trypsin hydrolysates, obtained from the head and bone of the hybrid grouper. This was in agreement with the findings of Barzideh et al. (2014), who reported that the Alcalase hydrolysate of ribbon jellyfish exhibited the highest ACEinhibitory activity at $1-3 \mathrm{~h}$ of hydrolysis $(\mathrm{DH}=28-30 \%)$. An increased in the hydrolysis time to $9 \mathrm{~h}(\mathrm{DH}=48 \%)$ however led to a decrease in activity. It is notable, that several studies contradicted this finding by attributing a higher ACE-inhibitory activity to a longer hydrolysis time. For instance, the ACE-inhibitory activity of Alcalase hydrolysate of Alaska Pollack skin increased by $15 \%$, under a hydrolysis time stretching from 1 to $24 \mathrm{~h}$ (Byun \& Kim 2001). Similarly, Miguel et al. (2004) reported that the IC50 of Trypsin hydrolysate of egg white, at $24 \mathrm{~h}$ hydrolysis time, was 6.5 times lower than at $30 \mathrm{~min}$ hydrolysis time. Unlike Alcalase and Trypsin, a positive correlation between DH and ACE-inhibitory activity was displayed by Proteinase $K\left(\mathrm{R}^{2}=0.631\right)$ and Pepsin $\left(\mathrm{R}^{2}=\right.$ $0.624)(p<0.01)$, respectively. This indicates that these enzymes require a longer hydrolysis time, to produce more ACE-inhibitory peptides, from the head and bone of the hybrid grouper. This finding was in agreement with those reported on the Pepsin hydrolysate of sea cucumber (Ghanbari et al. 2015) and egg white (Miguel et al. 2004), whereby the ACE-inhibitory activity increased in tandem with the hydrolysis time.

According to the results obtained in the present study, the four investigated enzymes deliver different levels of ACE-inhibitory activity. Alcalase displayed the highest overall ACE-inhibitory activity throughout the hydrolysis time. This suggests that Alcalase has the capacity to produce more ACE-inhibitory peptides, from the protein in the by-product of the hybrid grouper. Previous studies conducted on sea cucumber (Forghani et al. 2012; Ghanbari et al. 2015), swiftlet saliva (Syarmila \& Aliah 2016), and snakehead fish sarcoplasmic protein (Ghassem et al. 2014) also showed that Alcalase hydrolysate comes with a higher level of ACE-inhibitory activity, than other studied
(A)

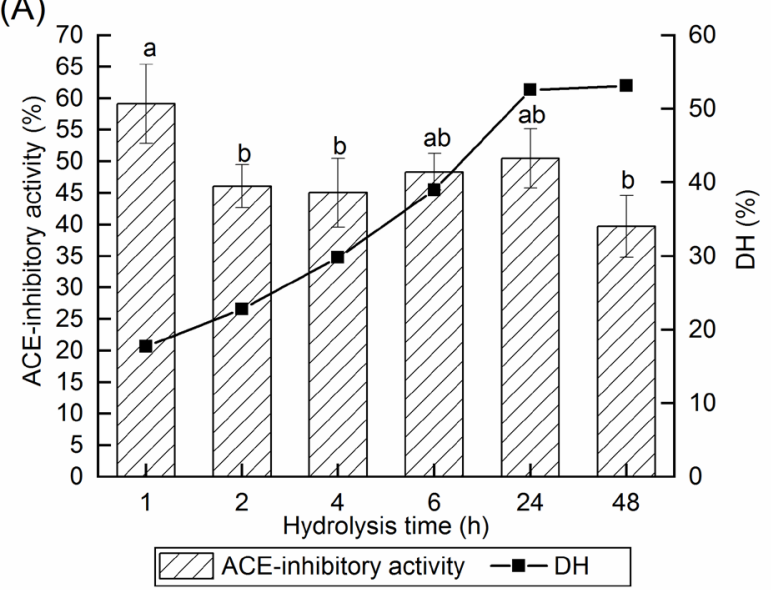

(C)

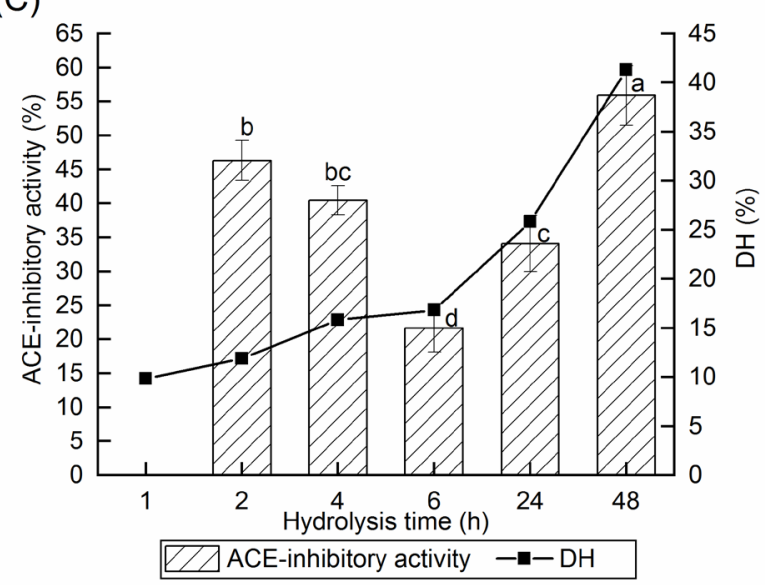

(B)

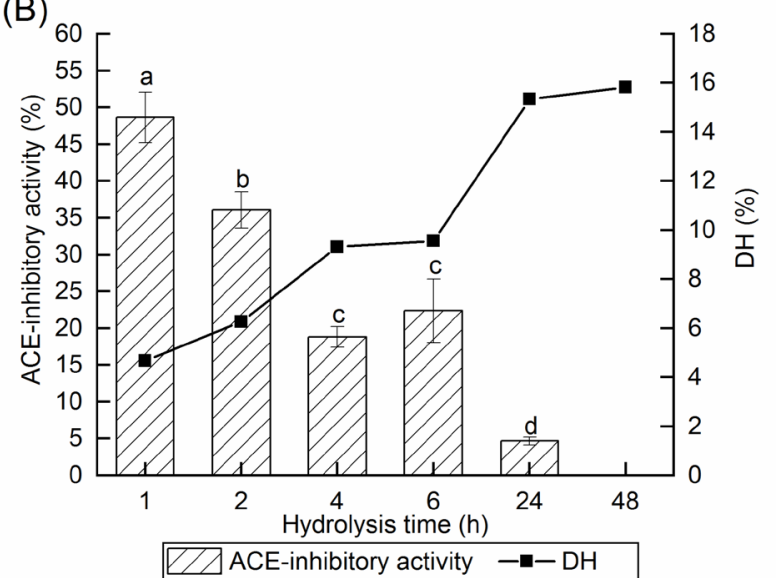

(D)

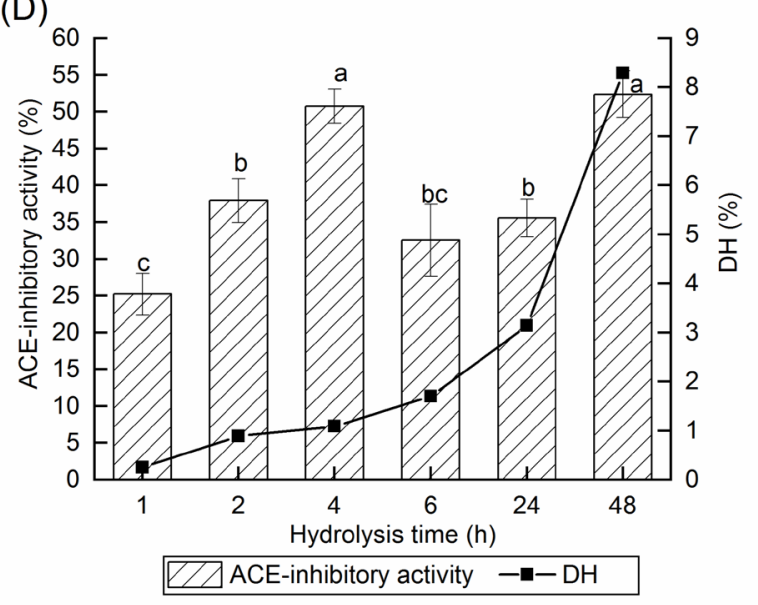

(a-d) different letter indicates significant difference at $\mathrm{p}<0.05$

FIGURE 2. The ACE-inhibitory activity and DH of protein hydrolysates hydrolysed by A) Alcalase, B) Trypsin, C) Proteinase K, and D) Pepsin over different hydrolysis time 
enzymes. In contrast, Qian et al. (2007) reported that Pepsin can produce more potent ACE-inhibitory hydrolysates than Alcalase, $\alpha$-chymotrypsin, Neutrase, Papain and Trypsin, from the dark muscle of tuna.

The type of enzyme used, and the duration of hydrolysis, produces peptides with different sequences in the hydrolysates. This brings about a variety of ACEinhibitory activities. For example, Alcalase and Pepsin hydrolysate exhibited a similar ACE-inhibitory activity of $51 \%$ at different hydrolysis times $(24 \mathrm{~h}$ and $4 \mathrm{~h}$, respectively). Meanwhile, with a similar DH of $16 \%$, Proteinase K hydrolysate showed better ACE-inhibition than Trypsin hydrolysate. These findings suggest that the peptide sequences in the hydrolysates, determine the ACEinhibitory activity performance, of the hydrolysate obtained. It has been established, that peptides containing hydrophobic (aromatic or branched side chains) amino acid residues, such as proline, tyrosine, and tryptophan at the C-terminal, demonstrated a considerable ACEinhibitory effect (Aluko 2012). Two examples of such peptides are Gly-Pro-Leu from Alaska Pollack (Byun \& Kim 2001), and Ala-Glu-Leu-Met-Met-Glu-Val-Asp-Pro from big eye tuna (Qian et al. 2007).

(A)

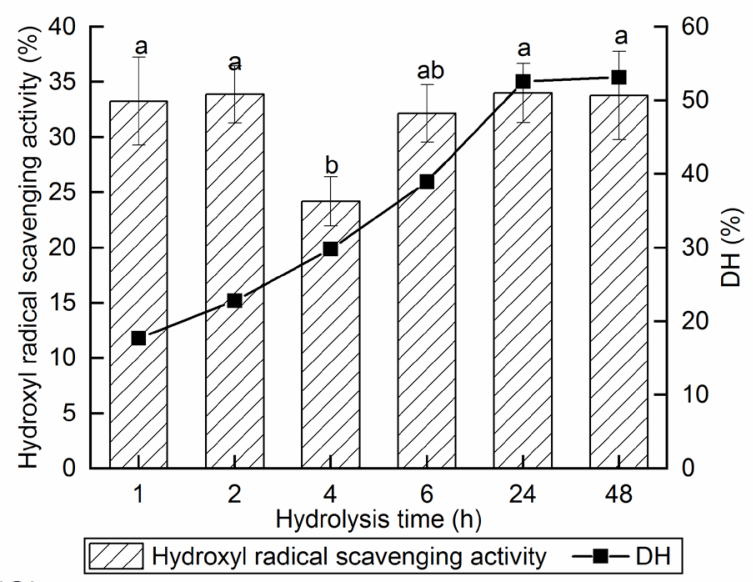

(C)

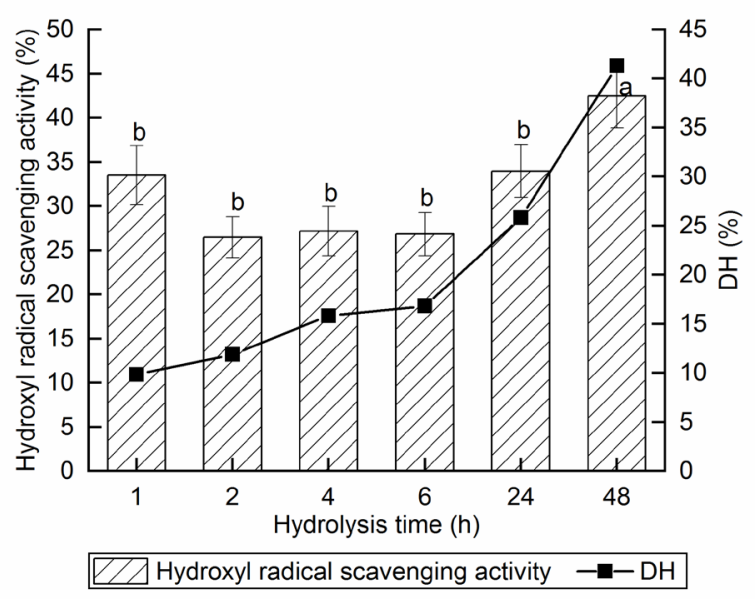

EFFECT OF HYDROLYSIS TIME ON THE ANTIOXIDANT ACTIVITIES OF HYDROLYSATES HYDROXYL RADICAL SCAVENGING ACTIVITY

The hydroxyl radical scavenging activity of hydrolysate, generated by different enzymes varies over hydrolysis time (Figure 3). The hydroxyl radical scavenging activity of Alcalase hydrolysate remains constant at roughly 34\% from 1 to $2 \mathrm{~h}$ of hydrolysis. Subsequent hydrolysis of up to $4 \mathrm{~h}$, led to a $24.18 \%(p<0.05)$ decline in activity (Figure $3(\mathrm{~A})$ ). However, prolonged hydrolysis of 24 and $48 \mathrm{~h}$, produced hydrolysates with improved activity, similar to the activity obtained from 1 and $2 \mathrm{~h}$ of hydrolysis $(p>$ $0.05)$. For Trypsin, an increase in the hydrolysis time, from 1 to $2 \mathrm{~h}$ significantly enhanced the hydroxyl radical scavenging activity by 1.6 times to $20.05 \%(p<0.05)$. However, this activity experienced a dropped to $5.32 \%(p$ $<0.05)$ after 4 h of hydrolysis $(\mathrm{DH}=9.31 \%)$ (Figure $3(\mathrm{~B})$ ). Further hydrolysis up to $6 \mathrm{~h}$ significantly increased the hydroxyl radical scavenging activity $(p<0.05)$. The activity continued to increase, until the highest level of activity was achieved at 24 and 48 h of hydrolysis. The effect of hydrolysis time was observed to be less profound for the hydrolysates of Proteinase K, in which insignificant

(B)

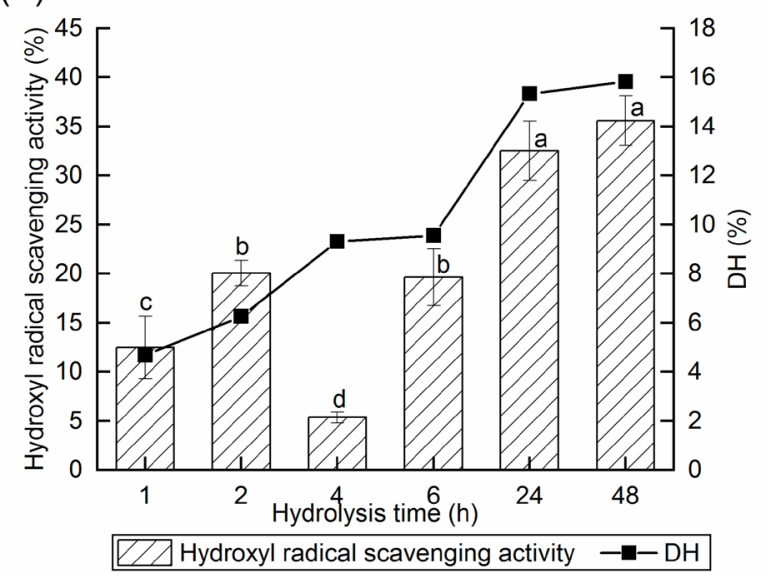

(D)

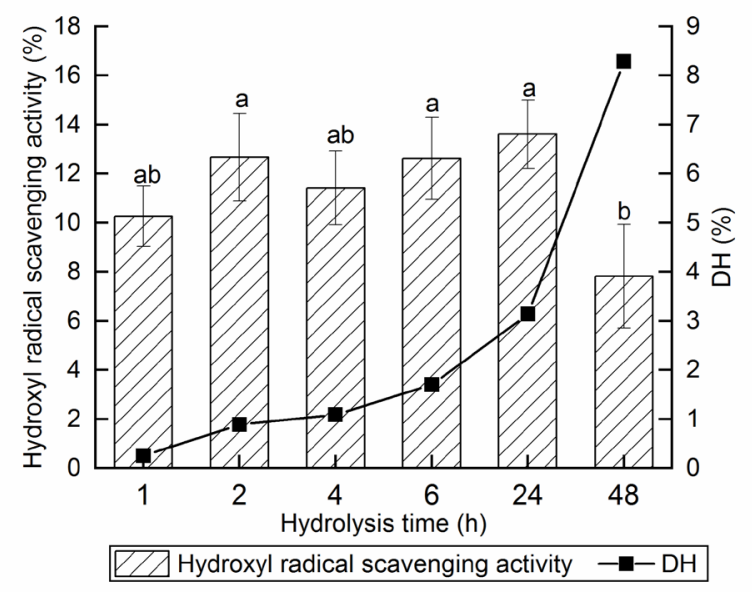

(a-d) different letter indicates significant difference at $\mathrm{p}<0.05$

FIGURE 3. The hydroxyl radical scavenging activity and DH of protein hydrolysates hydrolysed by A) Alcalase, B) Trypsin, C) Proteinase K, and D) Pepsin over different hydrolysis time 
differences were detected during the first $24 \mathrm{~h}$ of hydrolysis $(p>0.05)$, and the highest activity was achieved after 48 $\mathrm{h}$ of hydrolysis (42.47\%), as portrayed in Figure 3(C). This trend was observed to be similar for the hydrolysate of Pepsin during the initial $24 \mathrm{~h}$ of hydrolysis, but subsequent to $48 \mathrm{~h}$ of hydrolysis, the hydroxyl radical scavenging activity for the hydrolysate of Pepsin declined to $7.82 \%$ as shown in Figure 3(D).

In brief, the hydrolysate of Proteinase K, with $48 \mathrm{~h}$ of hydrolysis, recorded a higher level of hydroxyl radical scavenging activity (42.47\%) than the hydrolysates of Alcalase, Pepsin, and Trypsin. This is an indication, that Proteinase $\mathrm{K}$ has the capacity to generate bioactive peptides that come with a high radical scavenging ability, from the head and bones of the hybrid grouper. The low hydroxyl radical scavenging activity, displayed by the Pepsin hydrolysate in this study, is in contradiction to previous reports on marine sources. These sources include Exocoetus volitans backbones (Naqash \& Nazeer 2011) and tuna backbone (Je et al. 2007), where the Pepsin hydrolysate exhibited a higher hydroxyl radical scavenging ability, than the Trypsin and Alcalase hydrolysates.

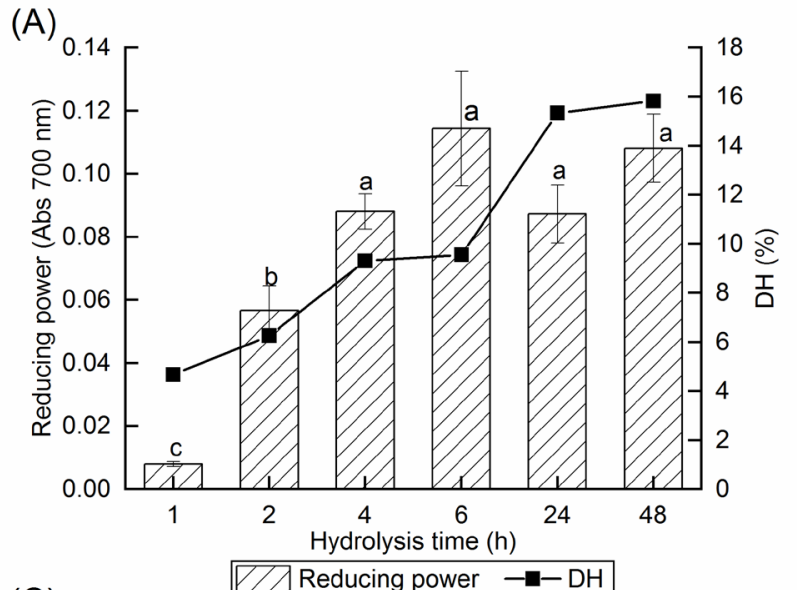

(C)

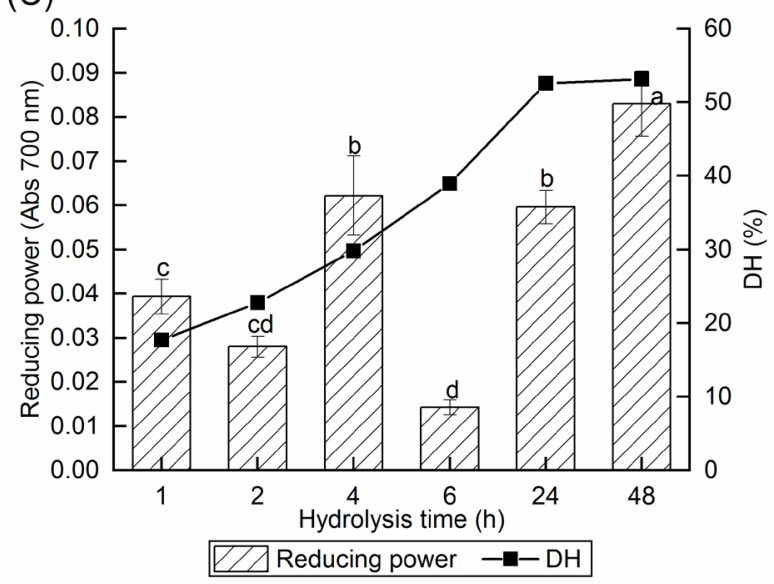

(a-d) different letter indicates significant difference at $\mathrm{p}<0.05$

FIGURE 4. The reducing power and DH of the protein hydrolysates hydrolysed by A) Trypsin, B) Pepsin, C) Alcalase, and D) Proteinase K over different hydrolysis time
(B)
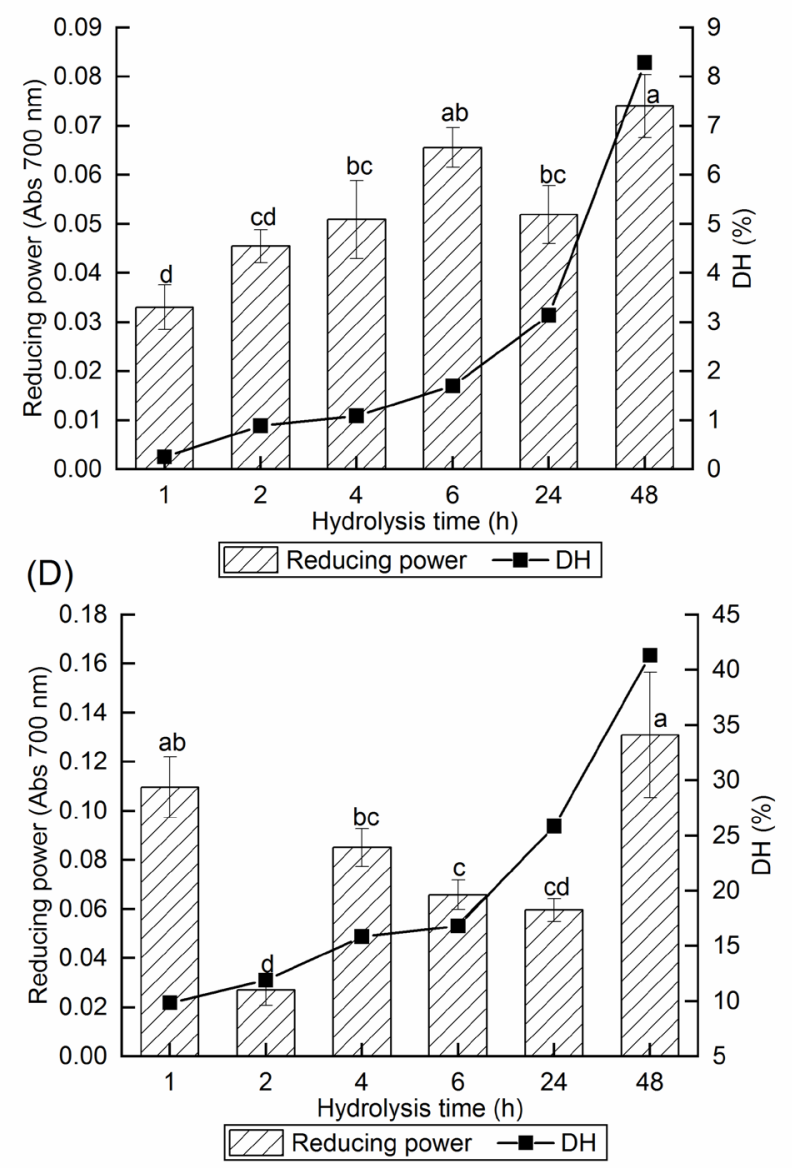

Both Trypsin and Proteinase $\mathrm{K}$ required require a longer hydrolysis time (up to $48 \mathrm{~h}$ ) to deliver peptides with a high scavenging ability. This is made evident, by the strong positive correlation between the $\mathrm{DH}$ and the hydroxyl radical scavenging activity, displayed by Trypsin $\left(\mathrm{R}^{2}=0.766\right)(p<0.01)$ and Proteinase $\mathrm{K}\left(\mathrm{R}^{2}=0.828\right)(p<$ $0.01)$. In contrast, the weak positive correlation $\left(\mathrm{R}^{2}=\right.$ $0.155)(p<0.05)$ observed for Alcalase, indicates that the hydroxyl radical scavenging activity of the hydrolysate, was not improved by the progression of hydrolysis. Unlike the other three enzymes investigated, the Pepsin hydrolysate exhibited a negative correlation between the $\mathrm{DH}$ and the hydroxyl radical scavenging activity $\left(\mathrm{R}^{2}=\right.$ -0.493) $(p<0.05)$. This suggests that a longer hydrolysis time may culminate in a decline of the scavenging ability of the peptides. An extended hydrolysis time, may also cause some previously generated bioactive peptides, to lose their bioactivity.

This study shows that all the investigated enzymes displayed dissimilar patterns of hydroxyl radical scavenging activity, throughout the hydrolysis period. In an investigation by Klompong et al. (2007), the radical 
scavenging activity of Alcalase-treated yellow stripe trevally peaked at DH of 5\%, but increasing in the DH to $15 \%$, significantly reduced the activity level, and the subsequent increase in the DH to $25 \%$ did not result in any changes to the radical scavenging activity. Previous studies on Bluefin leatherjacket heads (Chi et al. 2015), skipjack tuna bone (Yang et al. 2019) and silver carp by-products (Zhong et al. 2011) suggest that aromatic (histidine) and hydrophobic amino acids (proline and leucine) are contributors towards the hydroxyl radical scavenging ability of the peptides. This is attributed to the ability of these amino acids to participate in the hydrogen and electron transfer reaction, and consequently neutralise the free radicals (Aluko 2012). Amino acids analysis had been carried out in our laboratory and similar amino acids were found in the head and bones of the hybrid grouper (data not shown).

\section{REDUCING POWER}

As shown in Figure 4, with an hour of hydrolysis, the reducing power of Trypsin hydrolysate increased from $0.0079(1 \mathrm{~h})$ to the highest level of $0.1144(6 \mathrm{~h})(p<0.05)$. Further hydrolysis untill $48 \mathrm{~h}$ did not lead to any alteration in the reducing power $(p>0.05)$ (Figure 4(A)). A similar trend was exhibited by Pepsin hydrolysates, where the reducing power increased with 1 to $6 \mathrm{~h}$ of hydrolysis, then dropped slightly to 0.0519 at $24 \mathrm{~h}$, before rising to the highest level at $48 \mathrm{~h}(0.0740)(p<0.05)$, as shown in Figure 4(B). Alcalase and Proteinase K hydrolysates, on the other hand, demonstrated a different trend. During the hydrolysis period of 1 to $4 \mathrm{~h}$, the reducing power of Alcalase hydrolysate increased by $58.27 \%$, but then decreased significantly to 0.0143 after $6 \mathrm{~h}$ of hydrolysis $(p<0.05)$, as illustrated in Figure 4(C). Hydrolysis up to $48 \mathrm{~h}$ resulted in the greatest reducing power of $0.0830(p<0.05)$. The reducing power of Proteinase $\mathrm{K}$ hydrolysate was recorded as 0.1097 at the first hour of hydrolysis, then declined to 0.0596 after $24 \mathrm{~h}(0.0596)(p<0.05)$, as portrayed in Figure 4(D). Prolonged hydrolysis until $48 \mathrm{~h}$ elevated the reducing power to $0.1309(p<0.05)$.

The hydrolysates produced by the four mentioned enzymes exhibited different reducing power patterns throughout the $48 \mathrm{~h}$ of hydrolysis time. The highest reducing power for Alcalase, Proteinase $\mathrm{K}$ and Pepsin hydrolysate was recorded at the end of the hydrolysis period, i.e. $48 \mathrm{~h}$ with the $\mathrm{DH}$ at $53.12 \%, 41.30 \%$, and $8.29 \%$, respectively, while the highest reducing power for Trypsin hydrolysate was observed at $6 \mathrm{~h}$ of hydrolysis, with $\mathrm{DH}$ at $9.56 \%$. Due to enzyme specificity, the DH required to produce high antioxidant activity also differs according to the type of enzyme used. Generally, positive correlations were reported between reducing power and $\mathrm{DH}$ for all the four enzymes, with Trypsin $\left(\mathrm{R}^{2}=0.736\right)$ and Pepsin $\left(\mathrm{R}^{2}=0.771\right)(p<0.01)$ showing a stronger correlation than Alcalase $\left(\mathrm{R}^{2}=0.507\right)$ and Proteinase $\mathrm{K}$ $\left(\mathrm{R}^{2}=0.529\right)(p<0.05)$. These positive correlations, suggest that the reducing power of hydrolysates, was dependent on the availability of smaller peptide fragments, deriving from a longer hydrolysis time. This is contradictory to the finding from a study on Goby muscle, hydrolysed by the crude proteases extract from smooth hound, in which the highest reducing power was observed at $10 \% \mathrm{DH}$, and a further increase in the DH led to a decline in reducing power (Nasri et al. 2014).

\section{CONCLUSION}

Alcalase exhibited a greater affinity to the protein deriving from the head and bone of the hybrid grouper, by producing highest \% DH (48 h of hydrolysis) as compared to Proteinase K, Trypsin, and Pepsin. This enzyme was also able to produce the hydrolysate with the highest ACEinhibitory activity, at a short hydrolysis time of $1 \mathrm{~h}$. The effect of hydrolysis time, on the ACE-inhibitory activity of each enzyme hydrolysate varies. Prolonged hydrolysis time lowered the ACE-inhibitory activity of the Alcalase and Trypsin hydrolysates, but improved the activities of the Proteinase K and Pepsin hydrolysates. Generally, an extended hydrolysis time enhances the antioxidant activities of hydrolysates. Among the enzymes tested, Proteinase $\mathrm{K}$ recorded the highest antioxidant activities after $48 \mathrm{~h}$ of hydrolysis. The findings from this investigation indicate that the bioactivities of the hydrolysates were highly dependent upon the type of enzyme, and the hydrolysis period. As such, the selection of an appropriate enzyme, coupled with an effective hydrolysis period, is essential for the realisation of a high level of bioactivities. The results from this study also showed that a suitable enzyme and hydrolysis time is necessary, for acquiring a hydrolysate with substantial ACE-inhibitory and antioxidant activities, from the head and bones of a hybrid grouper. It is recommended that future studies in this area emphasise on the purification of specific bioactive peptides (with regards to ACE-inhibitory and antioxidant activities) deriving from the hydrolysate.

\section{ACKNOWLEDGEMENTS}

This work is supported by the Niche Research Grant Scheme (NRGS) provided by the Ministry of Higher Education, Malaysia (grant number NRGS0006).

\section{REFERENCES}

Adler-Nissen, J. 1993. Proteases. In Enzymes in Food Processing, edited by Nagodawithana, T. \& Reed, G. 3rd ed. San Diego: Academic Press Inc. pp. 167-199.

Aluko, R.E. 2012. Bioactive peptides. In Functional Foods and Nutraceuticals, edited by Aluko, R.E. New York: SpringerVerlag. pp. 37-61.

Ambigaipalan, P. \& Shahidi, F. 2015. Date seed flour and hydrolysates affect physicochemical properties of muffin. Food Bioscience 12: 54-60.

Barzideh, Z., Latiff, A.A., Gan, C. \& Alias, A.K. 2014. ACE inhibitory and antioxidant activities of collagen hydrolysates from the ribbon jellyfish (Chrysaora sp.). Food Technology and Biotechnology 52(4): 495-504. 
Byun, H.G. \& Kim, S.K. 2001. Purification and characterization of angiotensin I converting enzyme (ACE) inhibitory peptides from Alaska pollack (Theragra chalcogramma) skin. Process Biochemistry 36(12): 1155-1162.

Chalamaiah, M., Dinesh Kumar, B., Hemalatha, R. \& Jyothirmayi, T. 2012. Fish protein hydrolysates: Proximate composition, amino acid composition, antioxidant activities and applications: A review. Food Chemistry 135: 3020-3038.

Choonpicharn, S., Jaturasitha, S., Rakariyatham, N., Suree, N. \& Niamsup, H. 2014. Antioxidant and antihypertensive activity of gelatin hydrolysate from Nile tilapia skin. Journal of Food Science and Technology 52: 3134-3139.

Chi, C.F., Wang, B., Wang, Y.M., Zhang, B. \& Deng, S.G. 2015. Isolation and characterization of three antioxidant peptides from protein hydrolysate of Bluefin leatherjacket (Navodon septentrionalis) heads. Journal of Functional Foods 12: 1-10.

Coggins, P.C. \& Chamul, R.S. 2006. Food sensory attributes. In Handbook of Food Science, Technology, and Engineering, edited by Hui, Y.H. Boca Raton: CRC Press. pp. 58-26-58-31.

De, M., Mazlan, A.G. \& Simon, K.D. 2014. Temperature effect on gastric emptying time of hybrid grouper (Epinephelus spp.). AIP Conference Proceedings 1614: 616-618.

Ennaas, N., Hammami, R., Beaulieu, L. \& Fliss, I. 2015. Purification and characterization of four antibacterial peptides from protamex hydrolysate of Atlantic mackerel (Scomber scombrus) by-products. Biochemical and Biophysical Research Communications 462(3): 195-200.

Firdaus, R.F., Lim, L.S., Kawamura, G. \& Shapawi, R. 2016. Assessment on the acceptability of hybrid grouper, Epinephelus fuscoguttatus $\$ \times$ Epinephelus lanceolatus to soybean meal-based diets. AACL Bioflux 9(2): 284-290.

Forghani, B., Ebrahimpour, A., Bakar, J., Abdul Hamid, A., Hassan, Z. \& Saari, N. 2012. Enzyme hydrolysates from Stichopus horrens as a new source for angiotensinconverting enzyme inhibitory peptides. Evidence-Based Complementary and Alternative Medicine 2012: 1-9.

Franco-Miranda, H., Chel-Guerrero, L., Gallegos-Tintoré, S., Castellanos-Ruelas, A. \& Betancur-Ancona, D. 2017. Physicochemical, rheological, bioactive and consumer acceptance analyses of concha-type Mexican sweet bread containing lima bean or cowpea hydrolysates. $L W T$ - Food Science and Technology 80: 250-256.

Ghanbari, R., Zarei, M., Ebrahimpour, A. \& Abdul-Hamid, A. 2015. Angiotensin-I converting enzyme (ACE) inhibitory and anti-oxidant activities of sea cucumber (Actinopyga lecanora) hydrolysates. International Journal of Molecular Sciences 16: 28870-28885.

Ghassem, M., Babji, A.S., Said, M., Mahmoodani, F. \& Arihara, K. 2014. Angiotensin I-converting enzyme inhibitory peptides from snakehead fish sarcoplasmic protein hydrolysate. Journal of Food Biochemistry 38: 140-149.

Huang, G.R., Zhao, J. \& Jiang, J.X. 2011. Effect of defatting and enzyme type on antioxidative activity of shrimp processing by products hydrolysate. Food Science and Biotechnology 20(3): 651-657.

Jai Ganesh, R., Nazeer, R.A. \& Sampath Kumar, N.S. 2011. Purification and identification of antioxidant peptide from black pomfret, Parastromateus niger (Bloch, 1975) viscera protein hydrolysate. Food Science and Biotechnology 20(4): 1087-1094

Je, J.Y., Qian, Z.J., Byun, H.G. \& Kim, S.K. 2007. Purification and characterization of an antioxidant peptide obtained from tuna backbone protein by enzymatic hydrolysis. Process Biochemistry 42: 840-846.
Jumeri \& Kim, S.M. 2011. Antioxidant and anticancer activities of enzymatic hydrolysates of solitary tunicate (Styela clava). Food Science and Biotechnology 20(4): 1075-1085.

Kawasaki, T., Seki, E., Osajima, K., Yoshida, M., Asada, K., Matsui, T. \& Osajima, Y. 2000. Antihypertensive effect of valyl-tyrosine, a short chain peptide derived from sardine muscle hydrolyzate, on mild hypertensive subjects. Journal of Human Hypertension 14(8): 519-523.

Kim, S. \& Wijesekara, I. 2012. Industry perspectives and commercial trends for food proteins and biopeptides. In Food Proteins and Peptides: Chemistry, Functionality, Interactions, and Commercialization, edited by Hettiarachchy, N.S. Boca Raton: Taylor \& Francis Group. pp. 409-420.

Klompong, V., Benjakul, S., Kantachote, D. \& Shahidi, F. 2007. Antioxidative activity and functional properties of protein hydrolysate of yellow stripe trevally (Selaroides leptolepis) as influenced by the degree of hydrolysis and enzyme type. Food Chemistry 102(4): 1317-1327.

Ktari, N., Jridi, M., Bkhairia, I., Sayari, N., Ben Salah, R. \& Nasri, M. 2012. Functionalities and antioxidant properties of protein hydrolysates from muscle of zebra blenny (Salaria basilisca) obtained with different crude protease extracts. Food Research International 49: 747-756.

Li, X., Shen, S., Deng, J., Li, T. \& Ding, C. 2014. Antioxidant activities and functional properties of tea seed protein hydrolysates (Camellia oleifera Abel.) influenced by the degree of enzymatic hydrolysis. Food Science and Biotechnology 23(6): 2075-2082.

Miguel, M., Recio, I., Gomez-Ruiz, J., Ramos, M. \& LopezFandino, R. 2004. Angiotensin I-converting enzyme inhibitory activity of peptides derived from egg white proteins by enzymatic hydrolysis. Journal of Food Protection 7(9): 1914-1920.

Mirzaei, M., Mirdamadi, S., Ehsani, M.R., Aminlari, M. \& Hosseini, E. 2015. Purification and identification of antioxidant and ACE-inhibitory peptide from Saccharomyces cerevisiae protein hydrolysate. Journal of Functional Foods 19: 259-268.

Najafian, L. \& Babji, A.S. 2014. Production of bioactive peptides using enzymatic hydrolysis and identification antioxidative peptides from patin (Pangasius sutchi) sarcoplasmic protein hydolysate. Journal of Functional Foods 9: 280-289.

Naqash, S.Y. \& Nazeer, R.A. 2011. Evaluation of bioactive properties of peptide isolated from Exocoetus volitans backbone. International Journal of Food Science and Technology 46: 37-43.

Nasri, R., Jridi, M., Lassoued, I., Jemil, I., Ben Slama-Ben Salem, R., Nasri, M. \& Karra-Châabouni, M. 2014. The influence of the extent of enzymatic hydrolysis on antioxidative properties and ACE-inhibitory activities of protein hydrolysates from goby (Zosterisessor ophiocephalus) muscle. Applied Biochemistry and Biotechnology 173(5): 1121-1134.

Nielsen, P.M., Petersen, D. \& Dambmann, C. 2001. Improved method for determining food protein degree of hydrolysis. Journal of Food Science 66(5): 642-646.

Qian, Z.J., Je, J.Y. \& Kim, S.K. 2007. Antihypertensive effect of angiotensin I converting enzyme-inhibitory peptide from hydrolysates of bigeye tuna dark muscle, Thunnus obesus. Journal of Agricultural and Food Chemistry 55: 8398-8403.

Sun, Y., Hayakawa, S., Ogawa, M., Naknukool, S., Guan, Y. \& Matsumoto, Y. 2011. Evaluation of angiotensin I-converting 
enzyme (ACE) inhibitory activities of hydrolysates generated from byproducts of freshwater clam. Food Science and Biotechnology 20(2): 303-310.

Syarmila, E. \& Aliah, N. 2016. Effect of enzymatic hydrolysis on angiotensin converting enzyme (ACE) inhibitory activity in swiftlet saliva. International Food Research Journal 23(1): 141-146

World Health Organization (WHO). 2013. A Global Brief on Hypertension. Geneva: World Health Organization. pp. $1-40$.

Yang, X.R., Zhao, Y.Q., Qiu, Y.T., Chi, C.F. \& Wang, B. 2019. Preparation and characterization of gelatin and antioxidant peptides from gelatin hydrolysate of skipjack tuna (Katsuwonus pelamis) bone. Marine Drug 17(78): $1-18$.

Zakaria, N.A. \& Sarbon, N.M. 2018. Physicochemical properties and oxidative stability of fish emulsion sausage as influenced by snakehead (Channa striata) protein hydrolysate. $L W T$ Food Science and Technology 94: 13-19.

Zhong, S.Y., Ma, C.W., Lin, Y.C. \& Luo, Y.K. 2011 Antioxidant properties of peptide fractions from silver carp (Hypophthalmichthys molitrix) processing byproduct protein hydrolysates evaluated by electron spin resonance spectrometry. Food Chemistry 126: 16361642 .

Zuraini, A., Somchit, M.N., Solihah, M.H., Goh, Y.M., Arifah, A.K., Zakaria, M.S., Somchit, M., Rajion, M.A., Zakaria,
Z.A. \& Mat Jais, A.M. 2006. Fatty acid and amino acid composition of three local Malaysian Channa spp. fish. Food Chemistry 97: 674-678.

Pei-Teng, Chan, Patricia Matanjun \& Jau-Shya, Lee* Faculty of Food Science and Nutrition

Universiti Malaysia Sabah, Jalan UMS 88400 Kota Kinabalu, Sabah

Malaysia

Cahyo Budiman

Biotechnology Research Institute

Universiti Malaysia Sabah, Jalan UMS

88400 Kota Kinabalu, Sabah

Malaysia

Rossita Shapawi

Borneo Marine Research Institute

Universiti Malaysia Sabah, Jalan UMS

88400 Kota Kinabalu, Sabah

Malaysia

*Corresponding author; email: jslee@ums.edu.my

Received: 21 March 2019

Accepted: 29 October 2019 